\title{
Implications of fasting on the energy metabolism and feed evaluation in ruminants
}

\author{
S.A. Chowdhury ${ }^{1}$ and E.R. Ørskov ${ }^{2}$ \\ 'Bangladesh Livestock Research Institute \\ Savar, Dhaka, Bangladesh \\ ${ }^{2}$ The Rowett Research Institute, Greenburn Road \\ Bucksburn, Aberdeen AB2 9SBH
}

(Received 31 Octobcr 1994: accepted 4 November 1994)

\begin{abstract}
Fasting metabolism is adapted to ensure the orderly mobilization of endogenous substrates and fucl for maintaining vital activity. When no exogenous energy is consumed it gives rise to a glucosc deficient condition; as a result gluconeogenesis from amino acids occurs which results in a higher excretion of $\mathrm{N}$ and a higher heat production. When therefore fasting metabolism is adopted as the reference level of metabolism when assessing energetic efticiency, efficiency appears higher below energy maintenance $(\mathrm{Km})$ than above $(\mathrm{K} f)$. When enough feed is given to mect the glucogenic demand of an animal, but no more, heat production falls to a minimum, which suggests that this value, rather than fasting heat loss, would be the appropriatc base for measuring the energetic efficiency of exogenous feed. In general about one-third of energy maintenance $\left(150 \mathrm{~kJ} / \mathrm{kg} \mathrm{W}^{0.75}\right.$ daily or $20 \mathrm{mmol}$ of glucose $/ \mathrm{kg} \mathrm{W}^{\text {n.75 }}$ daily) should be used for obtaining this minimum metabolic state in ruminants.
\end{abstract}

KEY WORDS: fasting, energy metabolism, feed evaluation, ruminants

\section{PHYSIOLOGY OF FASTING}

After prolonged fasting ruminant animals can no longer absorb exogenous nutrients and must utilize endogenous energy and protein to maintain vital activity. Depending on the duration of food deprivation, fasting induces the physiological adaptation characterized by hypoglycaemia (Blum et al., 1981; Rule et al., 1985), hyperlipidaemia (Di Marco et al., 1981; Rule et al., 1985), hyperketonaemia (Lyle et al., 1984 ; Rule et al., 1985) and hypoinsulinaemia (Rule et al., 1985; Ku Vera, 1988; MacDowell and Annison, 1991). These changes not only lower the metabolic activity of the active cell mass, but are also 
essential for the orderly mobilization of endogenous substrates and fuel during periods of restricted availability of exogenous substrates (Shetty, 1990). They are under complex hormonal control which has both short-term and long-term characteristics. If blood glucose concentrations falls, the first response will be an increase in hepatic gluconeogenesis and release of glucose from the liver. At the same time the secretion of insulin decreases and that of glucagon increases. If the situation becomes acute, glucoreceptors in the hypothalamus are stimulated to send impulses to the adrenal medulla for increased secretion of adrenaline. The reduced secretion of insulin and increased secretion of glucagon and adrenaline will further increase glycogenolysis but will also rapidly cause lipolysis in adipose tissue and mobilization of glycerol and free fatty acids. An increased use of intermediaries for amino acid or protein turnover will take place when tissues begin to provide energy-yielding substrates. Euglycaemia will be maintained by increased glyconeogenesis and also by reduced utilization of glucose lean and adipose tissue (Bergman, 1983). A shift in the substrate fuels used by the lean tissue occurs later with a preference for fatty acids and ketone bodies (Shetty, 1990).

\section{FASTING AND URINARY N EXCRETION}

During prolonged fasting $80-90 \%$ of energy expenditure is met by the oxidation of body fat (see Blaxter, 1962; Hovell ct al., 1977; Chowdhury, 1992). However, the energy requirement of body tissues cannot be met by lipid metabolism alone (Bergman, 1983). Glucose is essentially needed by at least five tissues of the body: (a) nervous system, (b) muscle, (c) fat synthesis and turnover, (d) foetus and (e) mammary gland (Bergman, 1983). During fasting deaminated amino acids contribute $70 \%$ of the glucose need through gluconeogenesis (Bergman, 1973). The nitrogenous part of the amino acid is converted into urea and excreted in the urine. The result is almost invariably a higher urinary $\mathrm{N}$ excretion during fasting than when the animals are fed to their minimum glucogenic need (Chowdhury, 1992). Fasting $\mathrm{N}$ excretion in ruminants is about $292 \mathrm{mg} / \mathrm{kg} \mathrm{W}^{0.75}$ daily $(A R C, 1980$ ). However, continuation of ruminal and hind gut fermentation at a low level tends to obscure the relationship between tissue metabolism and $\mathrm{N}$ excretion. The development of the intragastric nutrition technique (see Ørskov et al., 1979) makes possible an exact control over the protein : energy ratio in absorbed nutrients, which is not possible when rumen fermentation has to be sustained. Using this technique, several $\mathrm{N}$ balance studies have been carried out in sheep (Hovell et al., 1983, Asplund et al., 1985) and cattle (Ørskov et al., 1983; Ku Vera, 1988; Chowdhury et al., 1990), either without energy or protein, or with energy alone. These studies revealed that the fasting $\mathrm{N}$ excretion in ruminants was at least $350 \mathrm{mg} / \mathrm{kg} \mathrm{W}^{0.75}$ daily and could be more 
than $700 \mathrm{mg} / \mathrm{kg} \mathrm{W}^{0.75}$ daily, depending on the animal's maturity (Ørskov and Hovell, 1986). Moreover, sheep tend to have lower fasting $N$ excretion than cattle. For example in intragastrically-nourished steers daily fasting $\mathrm{N}$ excretion was found to be 641 (Ørskov et al., 1983), 510 (Lobley et al., 1987), 616 (Ku Vera, 1988), 633 (Chowdhury, 1992) and 429 (Hovell et al., 1983) $\mathrm{mg} / \mathrm{kg}^{0.75}$ daily. The degree of adiposity may also effect fasting $\mathrm{N}$ excretion (Ørskov, 1982). Ku Vera (1988) showed that fasting urinary $\mathrm{N}$ excretion in young immature steers was much higher (727 mg/kg W ${ }^{0.75}$ daily) than fat steers $\left(539 \mathrm{mg} / \mathrm{kg} \mathrm{W}^{0.75}\right.$ daily). Similarly, Chowdhury (1992) showed that lean sheep have higher fasting $\mathrm{N}$ excretion than fat sheep ( $460 \mathrm{vs} 360 \mathrm{mg} / \mathrm{kg} \mathrm{W}^{0.75}$ daily, respectively).

Urinary $\mathrm{N}$ excretion during fasting was found to be reduced by the provision of glucose or glucose substrate. Ørskov (1982) compared the N excretion in sheep and steers nourished by intragastric infusion either at energy maintenance or at fasting. In both species urinary $\mathrm{N}$ excretion during fasting was found to be about $40 \%$ higher than when an $\mathrm{N}$-free but othcrwise adequatc (in terms of energy, vitamins and minerals) infusion was given to meet the glucogenic demand of the animal (Chowdhury, 1992). Urinary $\mathrm{N}$ excretion has also been reported to be about $40 \%$ higher during fasting than at energy maintenance by Askbrant and Khalili (1990) in poultry, by Asplund et al. (1985) in sheep, and by Ku Vera (1988) in cattle.

\section{FASTING ELEVATES HEAT PRODUCTION}

On a net basis, biochemical changes are exothermic and encrgy is lost as heat. As fasting initiates a cascade of biochemical reactions, high heat production can be expected under this condition. Using the intragastric infusion technique,

TABLE 1

\begin{tabular}{cccccc}
\hline $\begin{array}{c}\text { Level of casein } \\
\text { infusion } \\
\left(\mathrm{mg} \mathrm{N} / \mathrm{Kg} \mathrm{W}^{0.75} \mathrm{~d}\right)\end{array}$ & $\begin{array}{c}\text { ME infused } \\
(\mathrm{KJ} / \mathrm{d})\end{array}$ & $\begin{array}{c}\text { Ileat Production } \\
(\mathrm{HP})\end{array}$ & $\begin{array}{c}\text { Change in HP } \\
(\mathrm{KJ} / \mathrm{d})\end{array}$ & $\begin{array}{c}\text { Heal increment } \\
\text { (Change in } \\
\text { HP/ME) }\end{array}$ & $\begin{array}{c}\text { Efficiency } \\
(\mathrm{KJ} / \mathrm{KJ} \text { infused }) \\
\text { retained }\end{array}$ \\
\hline${ }^{\mathrm{a}}$ Fasting & 0 & 335 & - & - & - \\
${ }^{\mathrm{b}}$ Basal & 91 & 325 & -10 & -0.11 & 1.11 \\
${ }^{\mathrm{c}} 250$ & 125 & 310 & -25 & -0.21 & 1.21 \\
${ }^{\mathrm{c} 500}$ & 157 & 300 & -35 & -0.22 & 1.22 \\
${ }^{\mathrm{c}} 750$ & 190 & 320 & -15 & -0.08 & 1.08 \\
${ }^{\mathrm{c}} 1500$ & 289 & 335 & 0 & 0 & 1.00 \\
${ }^{\mathrm{c}} 2250$ & 388 & 369 & 34 & 0.09 & 0.91 \\
${ }^{\mathrm{c}} 3000$ & 487 & 398 & 63 & 0.13 & 0.87 \\
\hline
\end{tabular}

\footnotetext{
${ }^{a}$ Energy and protein free infusion of mineral and vitamin solution

${ }^{b}$ Infusion of $91 \mathrm{KJ} / \mathrm{Kg} \mathrm{W}^{0.75} \mathrm{~d}$ of ME from a VFA mixture (of the molar proportions 16:79:5 of acetic : propionic : butyric acid), supplying $28 \mathrm{mmol}$ glucose $/ \mathrm{Kg} \mathrm{W}^{0.75} \cdot \mathrm{d}$

${ }^{c}$ Infusions of casein $\mathrm{N}$ together with $91 \mathrm{KJ} / \mathrm{Kg} \mathrm{W}{ }^{0.75} \mathrm{~d}$ of $\mathrm{ME}$ from the VFA mixture
} 
Chowdhury (1992) measured the heat production of two groups of sheep (Lighter, $39 \mathrm{~kg}$ and Heavier, $61 \mathrm{~kg}$ ) during fasting and also during the infusion of $0,250,500,750,1500,2250$ and $3000 \mathrm{mg} \mathrm{N} / \mathrm{kg} \mathrm{W}^{0.75}$ daily from casein along with $91 \mathrm{~kJ} / \mathrm{kg} \mathrm{W}^{0.75}$ daily of energy from a glucogenic VFA mixture (molar proportion of 16:79:5 of acetic : propionic : butyric acid). The results are shown in Table 1. It can be seen that heat production during fasting was high but that during the sequence of infusions it declined until $500 \mathrm{mg} \mathrm{N} / \mathrm{kg} \mathrm{W}^{0.75}$ daily was infused and then increased with the subsequent levels of infusion. Similarly, intra-abomasal infusion of glucose to a fasted stcer maintained by total intragastric infusion, reduced heat production (Ku Vera, 1988). Decreased heat production duc to nutrient supply to a fasted animal is completcly different from the well known heat increment effect of food intake, indeed there was a heat decrement. The components of the heat increment include the energy costs of eating and rumination as well as heat arising from the enzymatic hydrolysis of lipid, polysaccharides and protein, from the absorption of nutrients, from the effect of food on cellular activity e.g. protein turnover, $\mathrm{Na}^{+}, \mathrm{K}^{+}-$ATPase activity (Blaxter, 1989) and from the formation of urea. With animals on intragastric infusion, all the components of heat increment are possible except the energy cost of eating and rumination. Baldwin et al. (1980), regarded energy expenditure in the basal state as consisting of two functions, the service function $(36-40 \%$ of the total heat production) and the cellular maintenance function $(40-50 \%$ of the total heat production). During fasting, cellular maintenance functions like lipid and protein degradation increase to provide glucogenic and oxidative substrates (Iobley, 1991). Chowdhury (1992) showed that fasting heat production (332 $\mathrm{kJ} / \mathrm{kg} \mathrm{W}^{0.75}$ daily) of intragastrically nourished sheep was higher than the heat production $\left(290 \mathrm{~kJ} / \mathrm{kg} \mathrm{W}^{0.75}\right.$ daily) during infusion of a VFA mixture providing $91 \mathrm{~kJ} / \mathrm{kg} \mathrm{W}^{0.75}$ daily, whose propionate content was equivalent to approximately $28 \mathrm{mmol}$ glucose $/ \mathrm{kg} \mathrm{W} \mathrm{W}^{0.75}$ daily. He showed that $22 \%$ of the extra heat production (i.e. of $9.26 \mathrm{~kJ} / \mathrm{kg} \mathrm{W}^{0.75}$ daily) during fasting could be explained by increased protein oxidation $\left(3.7 \mathrm{mmol} u r e a / \mathrm{kg} \mathrm{W}^{0.75}\right.$ daily). Similarly, in intragastrically nourished steers, protein oxidation during fasting contributed $24 \%$ of the heal production (Ku Vera, 1988). During fasting, besides the energy cost of protein oxidation (approximately 4 moles of ATP per mole of urea or $5 \mathrm{~kJ}$ ME per gram of urea synthesized), additional heat production is associated with lipolysis and fatty acid oxidation (11 moles of ATP per mole of triglycerol).

\section{FASTING METABOLISM AS THE BASIS FOR ENERGY RLQUIREMENT}

In many feed evaluation systems fasting metabolism serves as the base line against which the efficiency of utilization of different feed stuffs is measured. The net energy requirement for maintenance is equal to the fasting metabolism plus 
TABLE 2

Effect of plane of nutrition on fasting metabolism of growing lams. All Values are in $\mathrm{KJ} / \mathrm{Kg} \mathrm{W} \mathrm{W}^{0.75}$ daily (from Fattet et a. 1985

\begin{tabular}{cccc}
\hline ME from straw & $\begin{array}{c}\text { Energy loss } \\
\text { expected }\end{array}$ & $\begin{array}{c}\text { Encrgy loss } \\
\text { found }\end{array}$ & $\begin{array}{c}\text { Estimated fasting } \\
\text { metabolism }^{j}\end{array}$ \\
\hline 285 & -206 & -107 & 272 \\
262 & -187 & -73 & 294 \\
456 & -51 & -37 & 356 \\
With fish meal & & & \\
307 & -155 & -32 & 247 \\
488 & -28 & -9 & 351 \\
\hline
\end{tabular}

"Calculated, assuming a fasting metabolism of $370 \mathrm{KJ} / \mathrm{Kg} \mathrm{W}^{075}$ daily and an efficiency of $\mathrm{ME}$ utilization of 0.70 (ARC, 1980)

${ }^{b}$ Calculated from energy loss found at slaughter and utilization of ME of 0.70

'Supplemented with protein and additional ME as fish meal

an allowance made for the animal's muscular activity (Ku Vera, 1988). In general the $\mathrm{ME}$ requirement for maintenance is about 1.35 times fasting heat production (Flatt, 1988). This has been criticized on several grounds by Marston (1948), Webster et al. (1974), Ku Vera (1988) and Ørskov and MacLeod (1990). When Marston (1948) fed sheep at half energy maintenance for 10 weeks and then fasted them, their mean fasting metabolic rate was $231 \mathrm{~kJ} / \mathrm{kg} \mathrm{W}^{0.75}$ daily. When the same sheep were fed at maintenance level for 10 weeks their mean fasting metabolism was $265 \mathrm{~kJ} / \mathrm{kg} \mathrm{W}^{0.75}$ daily. The fall in fasting metabolism due to undernutrition was $13 \%$. After the same sheep had been fed at twice maintenance, their fasting metabolic rate was $290 \mathrm{~kJ} / \mathrm{kg} \mathrm{W}^{0.75}$ daily. When the fasting heat production of Marston's sheep was plotted against their respective energy balances, there was approximately $0.2 \mathrm{~kJ} / \mathrm{kg} \mathrm{W}^{0.75}$ increase in fasting heat production for each $1 \mathrm{~kJ} / \mathrm{kg} \mathrm{W}^{0.75}$ increase in preceding energy balance. Fattet et al. (1984) gave different levels of ME from alkali treated straw alone or with fish meal to growing lambs. The estimated fasting metabolism was found to be increased with increase in ME intake (Table 2). Several other reports (Graham et al., 1974; Ferrel et al., 1976; Blaxter, 1962, 1989) have shown that fasting heat production decreases with prolonged low levels of feeding.

Fasting causes the metabolism of a higher proportion of fat than occurs when any food is given, resulting in a high concentration of plasma free fatty acids (FFA). The energetic efficiency of oxidation of this FFA largely depends on the availability of oxaloacetate in the tricarboxylic cycle, as the entry of acetyl-CoA to the cycle depends on the intramitochondrial concentration of oxaloacetate. An inadequate production of oxaloacetate during fasting results from deficiency of its precursors (glucose, propionate, lactate and amino acids) and also from high intramitochondrial NADH to NAD ratio, which drives much of the 
oxaloacetate to malate so that it is drawn into lipogenic and ketogenic pathways in place of glucose (Ballard et al., 1969; Bergman, 1973). The end result is that, oxaloacetate is actually insufficient to meet the animal's requirement.

Based on these considerations Ørskov (1982b) suggested that it is conceptually incorrect to use fasting metabolism as the baseline for assessing the efficiency of utilization of a nutritionally balanced diet as it represents the energy metabolism of a glucose deficient "diet" (i.e. body fat). Chowdhury (1992) showed that when only the glucogenic need of non-pregnant non-lactating sheep was met, there was a decrease in fasting heat and urinary $\mathrm{N}$ excretion, a decrease in the plasma concentrations of plasma urea, FFA and $\beta$-hydroxybutyrate and an increase in plasma glucose and insulin to levels similar to those seen with an infusion providing energy maintenance $(450 \mathrm{~kJ}$ ME from VFA and $400 \mathrm{mg}$ casein- $\mathrm{N} / \mathrm{kg} \mathrm{W}^{0.75}$ daily). This suggests that the specific physiological adaptation induced by fasting may be annulled by meeting the glucogenic demand of the animal. Ørskov and MacLeod (1990) therefore suggested that the assessment of energy utilization in response to energy supply should use as its baseline the energy balance of animals receiving about one-third of energy maintenance (about $150 \mathrm{~kJ} / \mathrm{kg} \mathrm{W}^{0.75}$ daily of VFA, molar proportion $65: 25: 10$ for acetic: propionic : butyric acid) rather than that of fasting animals, so that the requirement for glucose precursors was likely to be met and gluconeogenesis avoided. This is equivalent to approximately $20 \mathrm{mmol}$ of glucose $/ \mathrm{kg} \mathrm{W}^{0.75}$ daily. Chowdhury (1992) had previously suggested a slightly different baseline infusion, a VFA mixture providing about $91 \mathrm{~kJ} / \mathrm{kg} \mathrm{W}^{0.75}$ daily from a VFA mixture (molar proportion 16:79:5 for acctic : propionic : butyric acids), cquivalent to $28 \mathrm{mmol}$ of glucose $/ \mathrm{kg} \mathrm{W}^{0.75}$ daily. However, based on glucose oxidation rate during fasting, Lobley (1991) suggested that the actual glucose requirement for non-pregnant, non-lactating sheep ranges from $5.5-7.9 \mathrm{mmol} / \mathrm{kg}$ $\mathrm{W}^{0.75}$ daily. In view of the greater glucose oxidation rate of fed steers compared to sheep (41 vs. $35 \mathrm{~kJ}$, Bergman,1983), it seems that cattle may have a higher glucose requirement than sheep. Until detailed information is available on the glucose requirements of different species of animals under different physiological conditions, it may be reasonably safe to accept Ørskov's (1982b) proposition of one-third of energy maintenance as baseline of measuring the energetic efficiency of different feed, rather than fasting, thus ensuring that the $\mathrm{N}$ excretion and $\beta$-hydroxybutyrate is not clevated.

\section{FASTING METABOLISM AND THE CONCEPT OF Km AND Kf}

The ARC (1980) feeding system, originally devised by Blaxter (1962), makes allowance for two different efficiencies of energy utilization, namely the efficiency of utilization of $\mathrm{ME}$ for maintenance $(\mathrm{Km})$ and the efficiency of 
utilization of ME for fattening (Kf). To determine the $\mathrm{Km}$ and $\mathrm{Kf}$ values for individual diets, calorimetric measurements of responses in energy retention to increases in ME intake are simply made below $(\mathrm{Km})$ and above $(\mathrm{Kf})$ maintenance level of intake. Depending on the nature of the diet, the $\mathrm{Km}$ value ranges from $0.60-0.80$, and the Kf value from $0.25-0.50$ (Thomas, 1988). Chowdhury (1992) estimated the efficiency of the ME utilization at three submaintenance levels of energy supply. He showed that when fasting heat production is used as the base, as it is for $\mathrm{Km}$ estimation in ARC (1980) system, the $\mathrm{Km}$ value becomes greater than 1 at the first increments of energy (Table 1). Since a $\mathrm{Km}$ value in excess of unity can only occur when a dietary increment depresses metabolic rate it is clear that fasting metabolism is a wholly inappropriate baseline for such calculations. Ørskov (1982b) first suggested that the difference between $\mathrm{Km}$ and $\mathrm{Kf}$ values might be simply an artefact arising from the use of fasting metabolism as the basis of calculation. Differences in the efficiency of utilization of $\mathrm{ME}$ between below and above maintenance will be greatly reduced by use of a minimum rate of metabolism rather than fasting. Obviously, since biosynthetic and oxidative reactions follow Michaelis-Menten kinetics (Baldwin and Smith, 1983), as the level of intake increases greatly the efficiency of energy utilization is bound to decrease eventually according to a law of diminishing returns (Mercer, 1982). However, the diminishing response may not occur within normal levels of feed intake.

There is not yet sufficient experimental evidence to specify the different levels of feeding necessary to obtain the minimum metabolic rate under different physiological conditions. However, it is clear that fasting metabolism is a metabolic adaptation which should not be used as the basis for measuring the energetic efficiency of nutritionally balanced diets for animals. The difference between the values of $\mathrm{Km}$ and $\mathrm{Kf}$ will be greatly reduced if not wholly removed by using the minimum metabolic rate rather than the fasting metabolic rate. The minimum metabolic rate may be obtained by meeting only the glucogenic demand of the animal. However, research is needed to determine the glucogenic demand of different species of animal under different physiological conditions. The use of the two components has led to several.

\section{REFERENCES}

Agricultural Research Council, 1980. The Nutrient Requirements of Ruminant Livestock. Commonwealth Agricultural Burcaux, Slough, England

Askbrant, S., Khalili, M., 1990. Estimation of endogenous energy and nitrogen losses in the cockerel during fasting and the post prandial. Brit. Poultry Sci. 31, 155-162

Asplund, J.M., Ørskov, E.R., Hovell, F.D.DeB., MacLeod, N.A., 1985. The effect of intragastric infusion of glucose, lipid or acetate on fasting nitrogen excretion and blood metabolites in sheep. Brit. J. Nutr. 54, 189-195 
Baldwin, R.L., Smith, N.E., 1983. Adaptation of metabolism to various conditions: Milk production. In: P.M. Riis (Editor). Dynamic biochemistry of animal production. World Animal Science, Basic Information 3. Elscvier Sci. Publ. pp. 359-388

Baldwin, R.L., Smith, N.E., Taylor, J., Sharp, P., 1980. Manipulating metabolic parameters to improve growth rate and milk secretion. J. Anim. Sci. 5I, 1416-1428

Ballard, F.J., Hanson. R.W. Kronfeld, D.S., 1969. Gluconeogenesis and lipogenesis in ruminant and non-ruminant animals. Fed. Proc. 28, 218-231

Bcrgman, E.N., 1973. Glucose metabolism in ruminants as related to hypoglycaemia and ketosis. Cornell Vet. 63, 341-382

Bergman, E.N., 1983. The pools of cellular nutrients: Glucose. In: P.M. Riis (Editor). Dynamic biochemistry of animal production. World Animal Science, A. Basic Information 3. Elsevier Sci. Publ. pp. 173-196

Blaxcr, K.L., 1962. The Energy Metabolism of Ruminants. Hutchinson and Co. Ltd, London

Blaxcr, K.L., 1989. Energy Metabolism in Animals and Man. Cambridge University Press, Cambridge, London, UK

Blum, J.W., Kunz, P., Bachman. C., Colombo. J.P., 1981. Metabolic effect of fasting in stecrs. Res. Vet. Sci. 31, 127-129

Chowdhury, S.A., 1992. Protein utilization during energy undernutrion in sheep. Ph.D. Thesis. University of Aberdeen, Aberdeen, UK

Chowdhury, S.A., Orskov, E.R., MacLeod, N.A., 1990. Protein utilization during energy undernutritrion in stecrs. Proc. Nutr. Soc., 49, 208A

Di Marco, N.M., Beitz. D.C.. Whitehurst, G.B., 1981. Effect of fasting on free fatty acids, glycerol and cholesterol concentrations in blood plasma and lipoprotein lipase activity in adipose tissue of cattle. J. Anim. Sci. 52, 75-82

Fattet, I., Hovel1, F.D.DeB., Orskov, E.R., Kyle, D.J., Pennie, K., Smart, R.I., 1984. Undernutrition in sheep. The effect of supplementation with protein on protein accretion. Brit. J. Nutr. 52 , $561-574$

Ferrel, C.L., Garrett, W.N., Hinman, M., Grichting, G., 1976. Energy utilization by pregnant and non-pregnant heifers. J. Anim. Sci. 42, 937-950

Flatt, W.P., 1988. Feed evaluation system: Historical background. In: E. R. Ørskov (Editor). World Animal Scicnce, B. Disciplinary Approach, pp. 1-18

Graham, N.McC., Scarle, T.W., Griffths, 1974. Basal metabolic rates in lambs and young sheep. Aust. J. Agric. Sci. 25, 957-971

Hovell, F.D.DeB., Gordon, J.G., MacPherson. R.M.. 1977. The Thin Sow. 2. Observations on energy and nitrogen exchanges of thin and normal sows in environmental temperatures of 20 and $5^{\circ} \mathrm{C}$. J. Agric. Sci., Camb. 89, 523-533

Hovell, F.D.DeB., Ørskov, E.R., Kylc. D., MacLeod, N.A., 1983. Basal urinary nitrogen excretion and growth response to supplemental protein by lambs close to energy equilibrium. Brit. J. Nutr. 51, 173-187

Ku Vera, J.C., 1988. Energy and metabolism in cattle nourished by intragastric infusion of nutrients. Ph.D. Thesis, University of Aberdeen, Aberdeen, UK

Lobley, G.E., 1991. Some interactions between protein and energy in ruminant metabolism. Proceedings of the International Symposium on Protein Metabolism and Nutrition. Vol. 1. EAAP Publ., pp. 38-39

I obley, G.E... Connel, A., Buchan, V., 1987. Fffect of food intake on energy and protein metabolism in finishing beef steers. Brit. J. Nutr. 57, 457-465

Lyle, R.R.. DeBoer, G., Harrison, R.O.. Young J.W., 1984. Plasma and liver metabolites and glucose kinetics as affected by prolonged ketonemia-glucosuria and fasting in stecrs. J. Dairy Sci. 47 , 2274-2282 
MacDowell, G.H., Annison, F.F., 1991. Hormonal control of encrgy and protein metabolism. In:

T. Tsuda, Y. Sasaki and R. Kawashima (Editors). Physiological aspects of digestion and metabolism in ruminants. Academic Press Inc., pp. 231-253

Marston, H.R., 1948. Encrgy transactions in sheep. Aust. J. Sci. Res. B, 1, 93-129

Mercer, L.P., 1982. The quantitative nutrient-response relation. J. Nutr. 112, 560-566

Orskov, E.R., 1982a. Protcin Nutrition in Ruminants. Academic Press, London

Orskov, E.R., 1982b. Discussion on maintenance and growth in ruminants: Introductory comment. In: A.E. Kcrn, F. Sundstol (Editors). Energy metabolism of farm animals. Agricultural University of Norway pp. 141-146

Orskov, F.R., Hovell, F.D.DcB., 1986. Protein metabolism and utilization during undernutrition in ruminants. In: Nuclear and Related Techniques in Animal Production and Health. International Atomic Fnergy Agency, Vienna, Austria, pp. 429-438

Ørskov, E.R., Grubb, D.A., Wenham, G., Corrigall, W., 1979. The sustenance of growing and faffening ruminants by intragastric infusion of volatile fatty acids and protein. Brit. J. Nutr. 38 , $397-405$

Ørskov, E.R., MacLeod, N.A., Fahmy, S.T.M., Istasse, L., Hovcll, F.D.DcB., 1983. Investigation of nitrogen balance in dairy cows and steers nourished by intragastric infusion. Effect of submaintenance energy input with or without protein. Brit. J. Nutr. 50, 99-107

Rulc, D.C., Bcitz, D.C.. DeBoer. G., Lyle. R.R., Trenkel, R.II., Young, J.W., 1985. Changes in hormone and metabolite concentrations in plasma of stecrs during a prolonged fast. $\mathrm{J}$. $\Lambda$ nim. Sci. $61,868-875$

Shetty, P.S., 1990. Physiological mechanisms in the adaptice response of metabolic rates to energy restriction. Nutr. Res. Rev, 3, 49-74

Thomas, P.C., 1988. Feed Evaluation - Tnergy. In: E.R. Ørskov (Editor). World Animal Science. B. Disciplinary Approach, pp. 51-76

Webster, A.J.F., Brockway, J.M., Smith, J.M., 1974. Prediction of energy requirements for growth in beef cattle. 1. The irrelevance of fasting metabolism. Anim. Prod. 19. 127-139

\section{STRESZCZENIE}

\section{Rozważania nad wplywem głodzenia na przemianę energii i wartościowanic pasz przċuwaçy}

Metabolizm u præėuwaczy w stanic glodzenia przystosowuje się do mobilizacji rezerw endogennych substratów i źródeł cnergii zapewniających aktywność życiową. Přy braku energii egzogennej zwiększa się deficyt glukozy, a w jego następstwie glukoza produkowana jest $z$ aminokwasów w procesie glukoneogenezy co, z kolei, prowadzi do zwiększenia wydalania azotu i więk szej produkcji ciepła. A zatem, gdy wartość premiany energii w stanje na czczo przyjmic się jako wskażnik poziomu metabolizmu przy ocenie wydajności energetycznej, to tak obličona wydajność jest znacznie poniżej energetycznych potrzeb bylowych $(\mathrm{Km})$ niż powyżej potrzeb cnergetycznych na opas (Kก). Przy poziomie żywienia nic wį̧kszym niż pokrywającym zapotrzebowanie zwierzęcia na glukoz̨̨ produkcja cicpla spada do minimum wskazując, je właśnie ta wartość, a nic wartość strat ciepła w stanie na czczo, powinna słanowić właściwą podstawę do pomiaru wydajności energetycznej paszy egzogennej. Wnioskujc siç, żc około $1 / 3$ energii butowej $(150 \mathrm{~kJ} / \mathrm{kg} \mathrm{W}$./s driennie lub $20 \mathrm{mmol}$ glukozy/kg $\mathrm{W}^{0.75}$ dziennie) powinno się pr yjmować dla uzyskania mininalncgo stanu przemian u przeżuwaczy. 